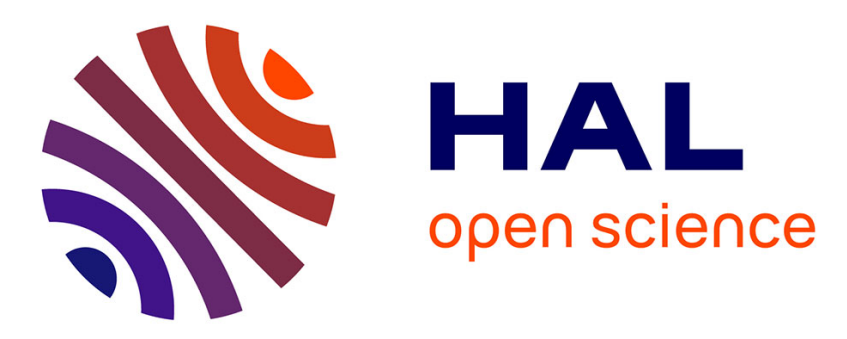

\title{
Influence of various redox conditions on the degradation of microalgal triacylglycerols and fatty acids in marine sediments
}

\author{
Sarah Caradec, Vincent Grossi, Franck Gilbert, Catherine Guigue, Madeleine
} Goutx

\section{To cite this version:}

Sarah Caradec, Vincent Grossi, Franck Gilbert, Catherine Guigue, Madeleine Goutx. Influence of various redox conditions on the degradation of microalgal triacylglycerols and fatty acids in marine sediments. Organic Geochemistry, 2004, vol. 35, pp. 277-287. 10.1016/j.orggeochem.2003.11.006 . hal-00780275

\section{HAL Id: hal-00780275 \\ https://hal.science/hal-00780275}

Submitted on 23 Jan 2013

HAL is a multi-disciplinary open access archive for the deposit and dissemination of scientific research documents, whether they are published or not. The documents may come from teaching and research institutions in France or abroad, or from public or private research centers.
L'archive ouverte pluridisciplinaire HAL, est destinée au dépôt et à la diffusion de documents scientifiques de niveau recherche, publiés ou non, émanant des établissements d'enseignement et de recherche français ou étrangers, des laboratoires publics ou privés. 


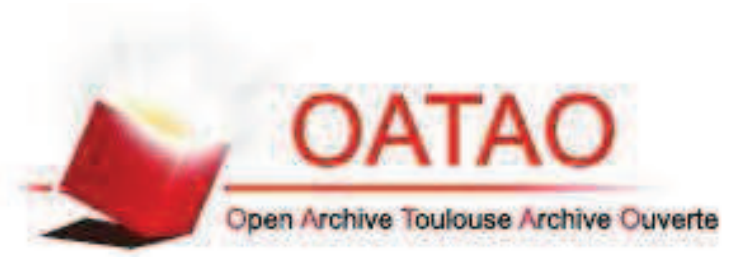

\section{Open Archive Toulouse Archive Ouverte (OATAO)}

OATAO is an open access repository that collects the work of Toulouse researchers and makes it freely available over the web where possible.

This is an author-deposited version published in: http://oatao.univ-toulouse.fr/ Eprints ID: 6101

To link to this article: DOI:
10.1016/j.orggeochem.2003.11.006
URL: http://dx.doi.org/10.1016/j.orggeochem.2003.11.006

To cite this version: Caradec, Sarah and Grossi, Vincent and Gilbert, Franck and Guigue, Catherine and Goutx, Madeleine Influence of various redox conditions on the degradation of microalgal triacylglycerols and fatty acids in marine sediments. (2004) Organic Geochemistry, vol. 35 ( $\mathrm{n}^{\circ}$ 3). pp. 277-287. ISSN 0146-6380

Any correspondence concerning this service should be sent to the repository administrator: staff-oatao@,listes.diff.inp-toulouse.fr 


\title{
Influence of various redox conditions on the degradation of microalgal triacylglycerols and fatty acids in marine sediments
}

\author{
Sarah Caradec ${ }^{\mathrm{a}}$, Vincent Grossi ${ }^{\mathrm{a}, *}$, Franck Gilbert $^{\mathrm{a}}$, Catherine Guigue ${ }^{\mathrm{b}}$, \\ Madeleine Goutx ${ }^{\mathrm{b}}$ \\ ${ }^{a}$ Laboratoire d'Océanographie et de Biogéochimie, Centre d'Océanologie de Marseille, UMR 6535-CNRS, Faculté des Sciences \\ de Luminy, case 901, 13288 Marseille Cedex 09, France \\ ${ }^{\mathrm{b}}$ Laboratoire de Microbiologie Marine, Centre d'Océanologie de Marseille, UMR 6117-CNRS, Faculté des Sciences de Luminy, \\ case 907, 13288 Marseille Cedex 09, France
}

\begin{abstract}
Sediment cakes, supplemented with microalgal cells (Nannochloropsis salina), were incubated for 35 days under permanently oxic, oscillating (5d:5d changeover oxic/anoxic) and strictly anoxic conditions of oxygenation in diffusively "open" sedimentary systems. Total lipids $\left(\mathrm{T}_{\mathrm{Lip}}\right)$ and triacylglycerols $(\mathrm{TG})$ concentrations were monitored by thin layer chromatography-flame ionisation detection, whereas the concentrations of the main extractable (free + ester-bound) individual fatty acids $\left(\mathrm{C}_{16: 0}, \mathrm{C}_{16: 1}, \mathrm{C}_{18: 1}\right)$ were followed using gas chromatography-mass spectrometry. Under the three conditions of oxygenation, TOC, $\mathrm{T}_{\mathrm{Lip}}$ and $\mathrm{TG}$ showed a sharp decrease in concentration during the early days of incubation and seemed to stabilise thereafter, defining an apparent non degradable fraction $\left(\mathrm{G}_{\mathrm{NR}}\right)$. The $\mathrm{G}_{\mathrm{NR}}$ content was systematically higher in the anoxic incubation than under the oxic and oscillating conditions. The ratio of the main hydrolysis products of TG versus TG [(Free fatty acids + Monoacylglycerols + 1,2-Diacylglycerols)/TG], used as an indicator of the hydrolysis of TG, showed that the presence of oxygen in the sediments (oxic and oscillating conditions) stimulates the hydrolysis of TG and the subsequent degradation of their metabolites. Unlike TOC, $\mathrm{T}_{\mathrm{Lip}}$ and TG, individual fatty acids (FA) showed a continuous concentration decrease until the end of the experiment, which was fitted with a simple first order model $\left[\mathrm{G}_{(\mathrm{t})}=\mathrm{G}_{0} \mathrm{e}^{-\mathrm{kt}}\right]$ to yield apparent degradation rate constants. The values observed under oscillating conditions $\left(\mathrm{k}_{\mathrm{FA}}=0.019 \pm 0.001 \mathrm{~d}^{-1}\right)$ were intermediate to those observed during oxic $\left(\mathrm{k}_{\mathrm{FA}}=0.029 \pm 0.003 \mathrm{~d}^{-1}\right)$ and anoxic $\left(\mathrm{k}_{\mathrm{FA}}=0.011 \pm 0.001 \mathrm{~d}^{-1}\right)$ incubations, and no significant difference between individual FA could be observed. The production of saturated and monounsaturated $\mathrm{C}_{16}$ (and to a lesser extent $\mathrm{C}_{18}$ ) alkanols under oscillating and anoxic redox conditions suggested that (a part of) the dominant FA were reduced to the corresponding alcohols under anoxic conditions, following their release from acylglycerols.
\end{abstract}

Keywords: Triacylglycerols hydrolysis; Fatty acids; Redox conditions; Nannochloropsis salina; Kinetics of degradation; Bioturbation; Superficial sediments

\footnotetext{
* Corresponding author. Tel.: + 33-491-829-651; fax: + 33-491-826-548.

E-mail address: grossi@com.univ-mrs.fr (V. Grossi).
} 


\section{Introduction}

Senescent (phyto)plankton sinking through the water column constitutes a major source of organic detritus for marine sediments. Among the major constituents of plankton, lipids are often used as biomarkers to study the source, transformation and fate of organic matter (Hedges and Prahl, 1993). The decomposition of lipids in near surface sediments is influenced by various factors such as their origin (aquatic vs. terrigeneous), their inherent structures (e.g. free molecules vs. combined forms), and the redox conditions encountered (Harvey and Macko, 1997; Hulthe et al., 1998; Sun et al., 1997, 2002; Sinninghe Damsté et al., 2002).

The influence of oxygen content on organic matter (OM) preservation has been much debated and studies comparing aerobic and anaerobic degradation have reached contrasting conclusions. Some studies have suggested that oxygen has no significant impact on the rate of OM degradation, which may rather be influenced by the age, origin, chemical composition or the structure of the OM (Kristensen and Blackburn, 1987; Lee, 1992; Kristensen et al., 1995). Other studies showed that the degradation of a variety of organic components, including lipids, is largely controlled by oxygen and that aerobic degradation is generally faster than anaerobic degradation (Harvey and Macko, 1997; Bianchi et al., 2000; Sun et al., 1997, 2002), indicating a dominant control of oxygen on $\mathrm{OM}$ preservation. It was also demonstrated that organic carbon burial efficiency is inversely correlated with the length of time accumulating particles are exposed to molecular oxygen in sedimentary pore waters (Hartnett et al., 1998; Hedges et al., 1999). At a molecular level, it seems that no single rule can be drawn as the two lines of thought may overlap. The degradation of organic substrates reflects both the influence of the chemical structure and the presence of oxygen. For instance, fatty acids can be degraded at similar rates independently of their degree of saturation in the presence of oxygen, whereas unsaturated acids are preferentially degraded under anoxic conditions (Harvey and Macko, 1997; Sun et al., 1997; Grossi et al., 2001).

In oxygenated sediments, bioturbation is a major process affecting redox conditions. Due to its reworking activity, the biological mixing alters aerobic/anaerobic boundaries and modifies the expression of the main bacterial processes, which influence the degradation of organic matter (Kristensen and Blackburn, 1987; Aller, 1994; Aller et al., 2001). In particular, the construction of tubes and burrows and their intermittent ventilation by benthic inhabitants allows the circulation of oxygenated water into anoxic parts of the sediment, which are thus subjected to oscillating conditions of oxygenation (Forster and Graf, 1992). Although it has been demonstrated that bioturbation can have a significant impact on the burial and degradation of sedimentary lipid components (e.g. Gilbert et al., 1994, 1996; Sun et al., 1999; Ingalls et al., 2000; Grossi et al., 2002, 2003), the influence of redox oscillation on lipid degradation has been little studied. Using a diffusively "open" incubation sedimentary system that mimics varying conditions of oxygenation in bioturbated sediments, Sun et al. (1993) showed that redox changes influenced the diagenetic pathways of chloropigments. More recently, using a similar experimental approach, these authors demonstrated that the frequency of oxic:anoxic oscillation could also alter the rates and pathways of degradation of individual cell-associated lipids (Sun et al., 2002).

Limited information is presently available concerning the influence of redox oscillation on the diagenesis of more complex phytoplanktonic lipids such as fatty acidcontaining macromolecular lipids (e.g. acylglycerols, phospholipids). To address this question, we used an experimental approach similar to that of Sun et al. $(1993,2002)$ to study the degradation of microalgal triacylglycerols in parallel with that of individual fatty acids under varying redox conditions. Sediment cakes supplemented with microalgal cells (Nannochloropsis salina; Eustigmatophyceae) were incubated under three contrasting conditions of oxygenation: permanently oxic, oscillating ( $5 \mathrm{~d}: 5 \mathrm{~d}$ changeover oxic/anoxic) and strictly anoxic. Using combined analytical approaches [thin layer chromatography-flame ionisation detection (TLC-FID) and gas chromatography (GC)], the fate of triacylglycerols (TG), their hydrolysis products [total free fatty acids (FFA), monoacylglycerols (MG) and diacylglycerols (DG)] and extractable (free + esterbound) individual fatty acids (FA) were monitored as a function of time and redox conditions.

\section{Experimental}

\subsection{Materials}

The sediment was collected using a multiple sediment corer (i.d. $15 \mathrm{~cm}$ ) at the SOFI Station in the Gulf of Lion, Mediterranean Sea $\left(43^{\circ} 04 \mathrm{~N}, 5^{\circ} 08 \mathrm{E} ; 170 \mathrm{~m}\right.$ depth$)$. At this station, the total organic carbon content of the sediment varies from 0.36 to $0.99 \%$ throughout the year (Schaaff et al., 2002). The station is continuously oxygenated and the sediment has an oxic layer of ca. 2.5 $\mathrm{mm}$. The sediment, preserved in isothermic bags, was transported to the laboratory where it was immediately stored at the in situ temperature $\left(15^{\circ} \mathrm{C}\right)$. Subsequently, the top layer of sediment $(0-1 \mathrm{~cm})$ was passed through a $0.250 \mathrm{~mm}$ mesh sieve to remove macrofauna and debris.

The marine microalga $N$. salina (Eustigmatophyceae) was chosen because of its high lipid and TG contents (Volkman et al., 1993; Schneider and Roessler, 1994). It was grown non-axenically to stationary phase at $15^{\circ} \mathrm{C}$ 
in $\mathrm{f} / 2$ medium (20 l) under continuous light conditions. Cells were harvested by centrifugation after the stationary phase had been reached for several days. Cells were freeze dried and mechanically mixed (30 min) with $600 \mathrm{ml}$ of sieved sediment. This increased the total organic carbon content (TOC) of the initial sediment from 0.37 to $1.6 \%$ and the total lipid content by ca. $54 \%$.

\subsection{Experimental set-up}

The experimental set-up was based on the diffusively "open" incubation method developed by Aller and Mackin (1989). The mixture of sediment and microalgal cells was poured into 44 polyvinylchloride (PVC) ring holders ( $68 \mathrm{~mm}$ i.d. $\times 2 \mathrm{~mm}$ thick). Two sediment plugs were immediately frozen (time zero) and 42 sediment plugs were distributed among nine containers (each containing 141 of $0.2 \mu \mathrm{m}$-filtered seawater) and were incubated for $35 \mathrm{~d}$ (darkness; $15{ }^{\circ} \mathrm{C}$ ) under different conditions of oxygenation (Fig. 1a). The overlying water in two sets of three containers was continuously purged with either air or a mixture of $\mathrm{N}_{2}-\mathrm{CO}_{2}$ (ca. $2.3 \% \mathrm{CO}_{2}$ ) to establish aerobic or strictly anaerobic conditions, respectively. The overlying water in the third set of three containers was purged alternatively with air or $\mathrm{N}_{2}-\mathrm{CO}_{2}$ ( $5 \mathrm{~d}$ changeover), creating oscillating conditions of oxygenation in the containers (Fig. 1b). The thickness of the plugs $(2 \mathrm{~mm})$ and their TOC content $(<2 \%)$ allowed the complete penetration of oxygen into the sediment

(a)

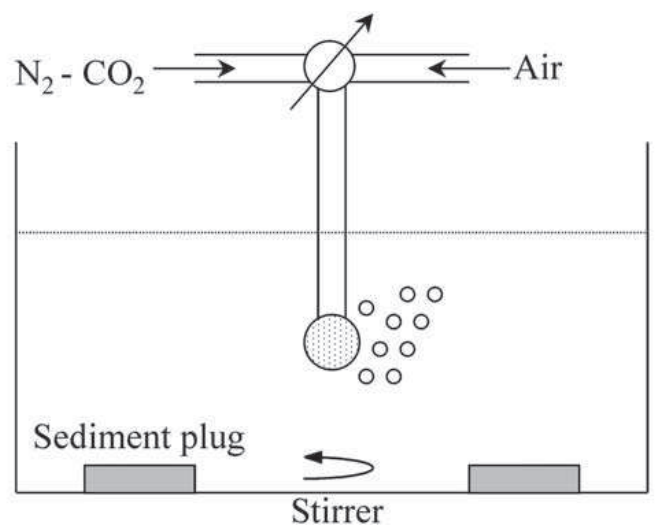

(b)

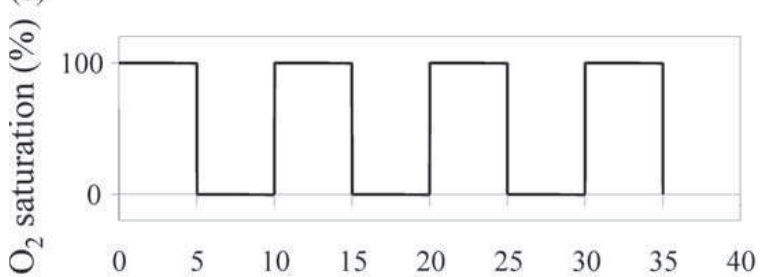

Fig. 1. (a) Open incubation experimental system (redrawn from Aller and Mackin, 1989); (b) Overlying water oxygen saturation under oscillating conditions. during the aerated conditions (Gilbert et al., 2003). Every 2-10 d, duplicate plugs were removed from each set of containers and kept frozen until analysis.

\subsection{TOC analysis}

TOC was analysed with a NA 1500 NC Carlo Erba elemental analyser (Fisons) on samples pretreated with $\mathrm{HCl}$ to remove inorganic carbon.

\subsection{Extraction of total lipids}

The lipids of the initial $N$. salina cells as well as those of each sediment plug were extracted ultrasonically with methanol $(\times 2)$, methylene chloride-methanol $(1: 1, \mathrm{v} / \mathrm{v}$; $\times 2)$ and methylene chloride $(\mathrm{DCM} ; \times 2)$. The combined extracts were concentrated by rotary evaporation and evaporated to dryness under nitrogen. Extracts were then split into sub-samples to analyse lipid classes by TLC-FID on one hand and individual fatty acids by GC and $\mathrm{GC}-\mathrm{MS}$ on the other.

\subsection{Analysis of lipid classes by TLC-FID}

Lipid classes were separated on Chromarods SIII (0.9 $\mathrm{mm}$ diameter, $150 \mathrm{~mm}$ length, $75 \mu \mathrm{m}$ silica thick) and quantified using a thin layer chromatograph-flame ionisation detector (TLC-FID) Iatroscan TH10 apparatus model MK-IV (Iatron, Japan); (hydrogen flow, $160 \mathrm{ml}$

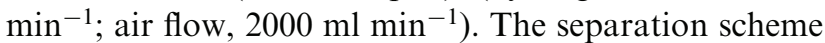
involved five elution steps in solvent systems of increasing polarity as described by Striby et al. (1999). Lipid classes were quantified with an external calibration using a mixture of standard lipids.

\subsection{Analysis of individual compounds by $G C$ and $G C-M S$}

Sub-samples of the total lipid extracts were saponified with $1 \mathrm{~N} \mathrm{KOH}$ in $\mathrm{MeOH} / \mathrm{H}_{2} \mathrm{O}(1: 1, \mathrm{v} / \mathrm{v}$, reflux $2 \mathrm{~h})$ to analyse free and ester-bound individual compounds. After extraction of the neutral lipids from the basic solution ( $n$-hexane, $3 \times 20 \mathrm{ml}$ ), acids were extracted (DCM, $3 \times 20 \mathrm{ml}$ ) following addition of $\mathrm{HCl}(\mathrm{pH}=2)$. Alcohols and fatty acids were converted to trimethylsilyl ether derivatives by reaction with bis-trimethylsilyl-trifluoroacetamide (BSTFA, Supelco) in pyridine $(1: 1 \mathrm{v} / \mathrm{v}$; $30 \mathrm{~min}$ at $60{ }^{\circ} \mathrm{C}$ ), and were identified with a HP 5890 Series II Plus gas chromatograph coupled to a HP 5972 mass spectrometer (Grossi et al., 2001). Individual compounds were quantified with an external standard calibration (squalane and nonadecanoic acid for alcohols and acids respectively) by gas chromatography using a HP4890 GC/FID system equipped with a HP$5 \mathrm{MS}$ capillary column $(30 \mathrm{~m} \times 0.25 \mathrm{~mm}$ i.d. $\times 0.25 \mu \mathrm{m}$ film thickness; Grossi et al., 2003). 


\subsection{Isolation and identification of TG fatty acids in N. salina}

A total lipid extract of the initial culture of $N$. salina was separated by thin layer chromatography (silica gel $\mathrm{G}$ plates; thickness $0.25 \mathrm{~mm}$ ) with $n$-hexane-diethylether-formic acid $(85: 15: 1, \mathrm{v} / \mathrm{v})$ as eluant. On a separate plate, standard lipids (triolein and olive oil, Sigma) were eluted and revealed using iodine to determine the response factor of triacylglycerols $\left(R_{\mathrm{f}}=0.39\right)$. The microalgal TG band [not revealed with iodine in order to avoid the degradation of polyunsaturated fatty acids (PUFAs)] was then scraped off the former TLC plate and TG were ultrasonically extracted from the silica before being saponified as described above. The released fatty acids were silylated and identified by GC-MS. Another total lipid extract of $N$. salina was directly saponified to determine the total free plus esterified fatty acid composition of the initial culture.

\subsection{Kinetics of decay}

For those classes of organic components whose concentrations stabilised before the end of the experiment (TOC, $\mathrm{T}_{\text {Lip }}, \mathrm{TG}$ ), we defined a simple 1-G model in which a reactive fraction $\left(\mathrm{G}_{01}\right)$ follows an exponential decrease in concentration with time (i.e. first-order decay, $\mathrm{k}_{1}$ ) and a resistant fraction which is not degraded during the experiment $\left(\mathrm{G}_{\mathrm{NR}}\right.$; $\mathrm{cf}$. Westrich and Berner, 1984). Attempts to use a $2 \mathrm{G}$-model did not allow us to distinguish two fractions having distinct reactivity $\left(\mathrm{G}_{01}\right.$ and $\mathrm{G}_{02}$; Westrich and Berner, 1984; Sempéré et al., 2000). The decrease in concentration was fitted using a least square minimization method (Solver function of Excel) of concentration versus time using the equation: $\mathrm{G}_{\mathrm{T}}(t)=\mathrm{G}_{01}\left[\exp \left(-\mathrm{k}_{1} t\right)\right]+\mathrm{G}_{\mathrm{NR}}$, where $\mathrm{G}_{\mathrm{T}}(t)=$ total concentration at time $t$.

Since individual fatty acid (FA) concentrations did not stabilise over the $35 \mathrm{~d}$ incubation, no $\mathrm{G}_{\mathrm{NR}}$ fraction could be considered. The decrease in concentration of these compounds was fitted using the equation $\mathrm{G}_{(t)}=\mathrm{G}_{0} \mathrm{e}^{-\mathrm{k} t}$ (where $\mathrm{G}_{(t)}=$ concentration of a component at time $t$ and $\mathrm{G}_{0}=$ original concentration). Apparent degradation rate constants $(\mathrm{k})$ were obtained from the slopes of log-transformed lipid concentrations versus time for each condition of incubation (Harvey and Macko, 1997).

\section{Results}

\subsection{Triacylglycerols and fatty acids of $\mathrm{N}$. salina in the initial plugs}

Iatroscan-analysed total lipids of the initial culture of $N$. salina revealed that $\mathrm{TG}$ were the major lipid class, representing $84 \%$ of the total lipid pool, whereas free fatty acids (FFA) accounted only for 3\% of the total lipids. The mixing of the sediment with $N$. salina cells induced an enrichment of ca. $100 \%$ for both classes of compounds. However, the proportion of $\mathrm{TG}$ relative to the total lipid fraction in the initial sediment plugs was $46 \%$ due to the presence of other lipid classes (hydrocarbons, pigments, phospholipids) in the original sediment.

The fatty acid composition of the isolated TG of the initial culture of $N$. salina was dominated by $\mathrm{C}_{16: 0}$, $\mathrm{C}_{16: 1(\mathrm{n}-7)}$ and $\mathrm{C}_{18: 1(\mathrm{n}-9)}$ components (32, 37 and 15\% respectively), together with smaller amounts of $\mathrm{C}_{14: 0}$, $\mathrm{C}_{18: 2}$ and $\mathrm{C}_{18: 0}$ fatty acids (4, 3 and 5\% respectively). Other fatty acids $\left(\mathrm{C}_{12: 0}, \mathrm{C}_{15: 0}, \mathrm{C}_{15: 1}, \mathrm{C}_{17: 0}, \mathrm{C}_{17: 1}, \mathrm{C}_{20: 0}\right.$, $\mathrm{C}_{22: 0}, \mathrm{C}_{24: 0}$ ) had a minor contribution whereas, surprisingly, $\mathrm{C}_{20}$ PUFAs $\left(\mathrm{C}_{20: 4}\right.$ and $\left.\mathrm{C}_{20: 5}\right)$ were not detected in TG and accounted for less than $2 \%$ of the fatty acids present in the total lipids. Due to the strong predominance of TG in $N$. salina cells and of $\mathrm{C}_{16: 0}, \mathrm{C}_{16: 1}$ and $\mathrm{C}_{18: 1}$ fatty acids in $\mathrm{TG}$, we focussed our analysis of individual fatty acids on these latter three compounds. These FA were also present in the initial sediment but, for each component, the contribution from the sediment always accounted for $<4 \%$ of the amount detected in the plugs.

\subsection{Patterns of TOC and total lipids decay}

TOC showed a similar pattern of loss under the different conditions of incubation (Fig. 2a). TOC concentrations decreased exponentially (by ca. 80\%) and seemed to reach a steady level by the end of the experiment. This suggests that only a reactive fraction of TOC $\left(\mathrm{G}_{01}\right)$ was degraded and that a refractory fraction $\left(\mathrm{G}_{\mathrm{NR}}\right)$ remained after 35 days. Decay constants calculated by the 1G-model (see Experimental) indicated that TOC was degraded slightly faster under anoxic conditions than under oxygenated conditions, the lowest decay constant being observed for fully oxic conditions (Table 1). A larger proportion of refractory material remained, however, by the end of the anoxic incubation whereas oscillating redox conditions resulted in the more extensive degradation of TOC (Table 1). Total lipid concentrations also showed a similar pattern of decay under the three redox regimes. However, their concentration rapidly dropped during the first 10 days before reaching a threshold value below which no further degradation could be observed (Fig. 2b). This plateau value (corresponding to the refractory fraction $\mathrm{G}_{\mathrm{NR}}$ ) varied from one condition to another: after 35 days of incubation, 44,49 and $59 \%$ of total lipids remained under oxic, oscillating and anoxic redox conditions, respectively (Table 1). It is noteworthy that the $1 \mathrm{G}$-model fitted to the data could not calculate reliable decay constants of total lipids for oscillating and anoxic 
conditions (Fig. 2b, Table 1), which might be due to the lack of measurements over the first five days.

\subsection{Patterns of $T G$ and individual $F A$ decay}

The patterns of microalgal TG degradation under the different redox conditions resembled those of TOC and $\mathrm{T}_{\text {Lip }}$, showing a sharp decrease in concentration during the early days of incubation (10 d for oxic and oscillating conditions and $5 \mathrm{~d}$ for the anoxic incubation), followed by a steady level until day 35 (Fig. 2c). Like TOC and $\mathrm{T}_{\mathrm{Lip}}$, the refractory fraction (calculated with the $1 \mathrm{G}$-model) by the end of the incubation period was higher under anoxic conditions (Table 1). The initial rate of TG hydrolysis however appeared higher under anoxic conditions.

Free fatty acids (FFA), monoacylglycerols (MG) and diacylglycerols (1,2-DG and 1,3-DG) are the main acyl lipid breakdown products of TG through enzymatic or chemical hydrolysis (Parrish, 1988; Goutx et al., 2003). FFA, MG and DG were not detected or were present in small amounts in the initial plugs, but were formed during the experiment. Although 1,3-DG could not be reliably quantified due to partial co-elution with other lipids during TLC-FID analysis, the ratio (FFA+ $\mathrm{MG}+1,2-\mathrm{DG}) / \mathrm{TG}$ could be used as an indicator of the hydrolysis of TG in the sediment plugs (Fig. 3). This ratio peaked at days 10 and 20 under oxic and oscillating conditions respectively, whereas it remained roughly stable in anaerobiosis.

Parallel to TG and their hydrolysis products, the fate of the major extractable (free + ester-bound) individual fatty acids $\left(\mathrm{C}_{16: 0}, \mathrm{C}_{16: 1}\right.$ and $\left.\mathrm{C}_{18: 1}\right)$ was followed using GC-FID and GC-MS. Unlike the global compound classes (i.e. TOC, $\mathrm{T}_{\text {Lip }}$, TG), individual FA showed a steady decrease in concentration under all conditions (Fig. 4). The highest extents of degradation of individual FA after 35 days were observed during the oxic incubation $(70-71 \%)$ and the lowest for the anoxic incubation (36-44\%; Table 2). It is possible, however, that a longer incubation time would have resulted in further degradation and/or in the characterisation of a non-degradable fraction for individual FA. For each condition of oxygenation, individual FA showed similar apparent degradation constants (calculated using a model in which no $\mathrm{G}_{\mathrm{NR}}$ is considered, see Experimental), but a
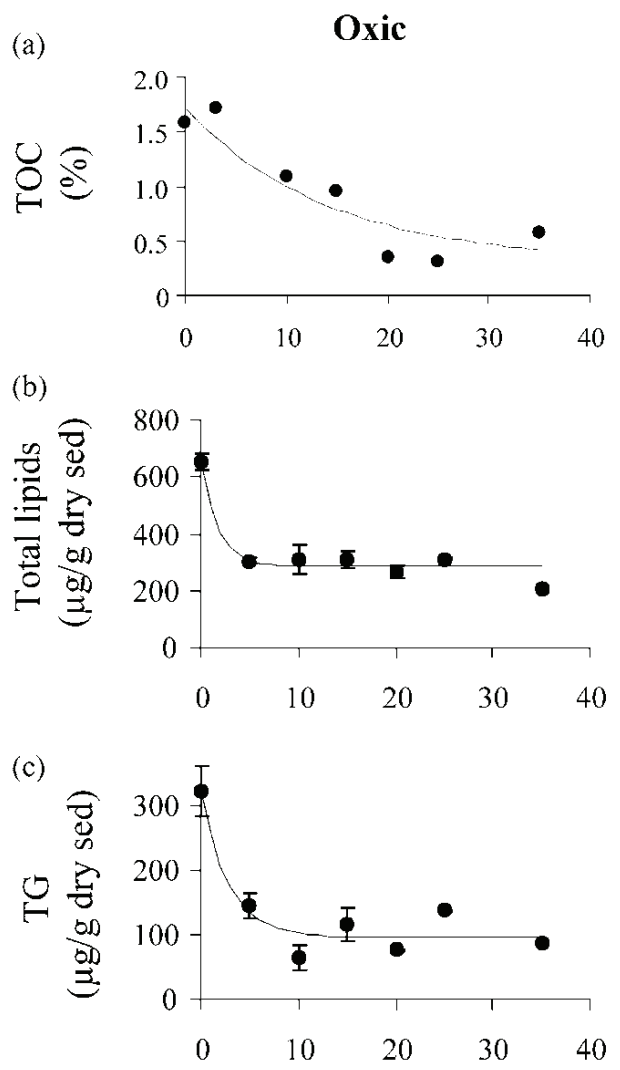
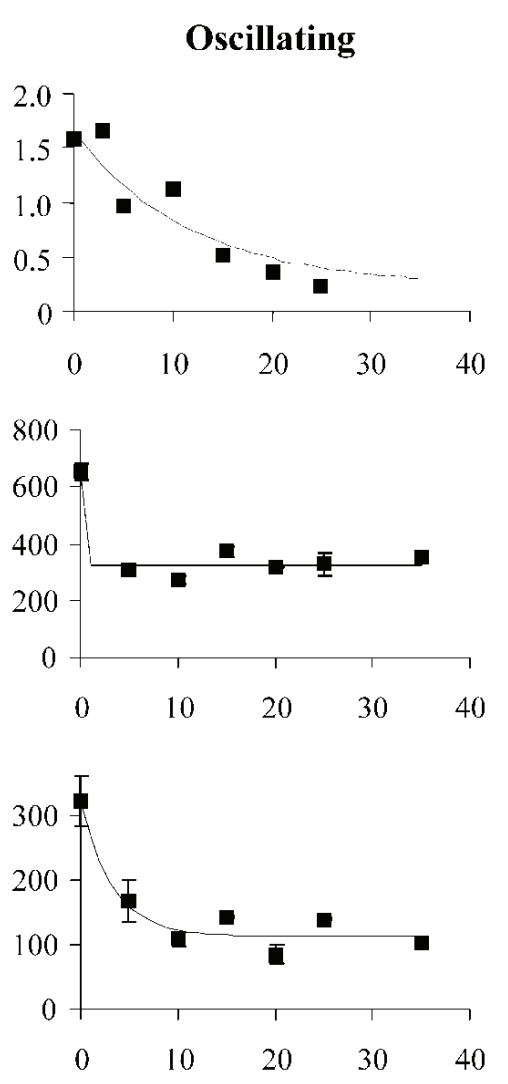

Time (d)
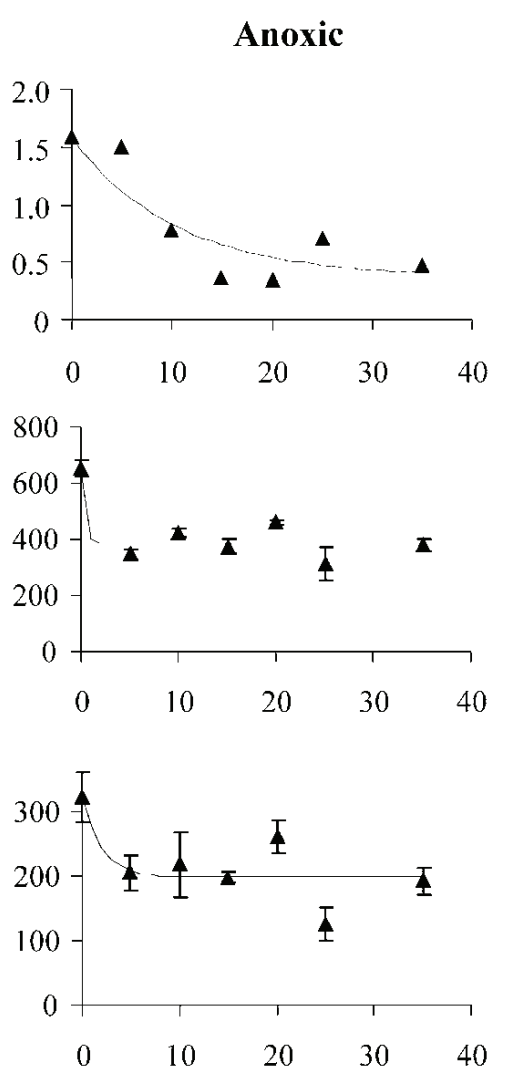

Fig. 2. Concentrations of (a) Total Organic Carbon (TOC), (b) Total lipids and (c) Triacylglycerols (TG) in N. salina-enriched sediment plugs incubated under oxic $(\boldsymbol{O})$, oscillating $(\boldsymbol{\square})$ and anoxic $(\boldsymbol{\Delta})$ redox conditions (each data point represents the average of duplicate samples \pm standard deviation, except for TOC). The solid lines are curves fitted to a 1-G model of the data (see Experimental). 
Oxic

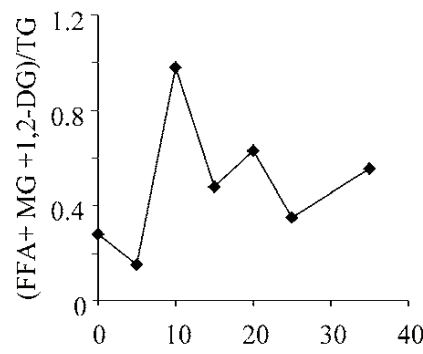

Oscillating

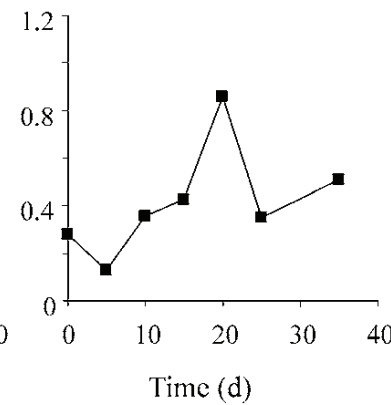

Anoxic

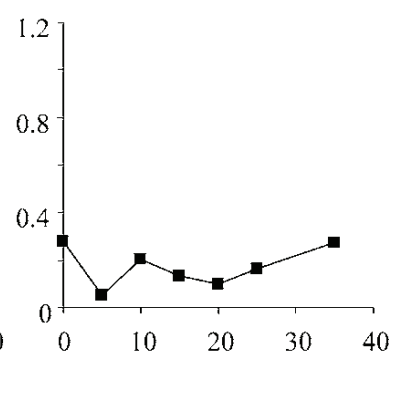

Fig. 3. Time-dependent ratio of the main TG hydrolysis products (FFA $+\mathrm{MG}+1,2-\mathrm{DG})$ vs TG during oxic ( anoxic ( $\mathbf{\Delta})$ incubations of $N$. salina-enriched sediment plugs.

Table 1

Coefficients of the $1 \mathrm{G}-$ model $\left(\mathrm{G}_{\mathrm{T}}(t)=\mathrm{G}_{01} \times\left[\exp \left(-\mathrm{k}_{1} t\right)\right]+\mathrm{G}_{\mathrm{NR}}\right)$ adjusted to TOC, total lipid and triacylglycerol concentrations (least-square minimization, Newton method) in sediment plugs incubated for 35 days under varying redox conditions ${ }^{\mathrm{a}}$

\begin{tabular}{llccc}
\hline Lipid & Coefficients & Oxic & Oscillating & Anoxic \\
\hline TOC & $\mathrm{G}_{01}$ & 82 & 86 & 77 \\
& $\mathrm{k}_{1}$ & 0.072 & 0.086 & 0.097 \\
& $\mathrm{G}_{\mathrm{NR}}$ & 18 & 14 & 23 \\
Total lipids & $\mathrm{G}_{01}$ & 56 & 51 & 41 \\
& $\mathrm{k}_{1}$ & 0.58 & $\mathrm{n} . \mathrm{d}$. & $\mathrm{n} . \mathrm{d}$. \\
& $\mathrm{G}_{\mathrm{NR}}$ & 44 & 49 & 59 \\
TG & & & & \\
& $\mathrm{G}_{01}$ & 70 & 65 & 38 \\
& $\mathrm{k}_{1}$ & 0.35 & 0.30 & 0.50 \\
& $\mathrm{G}_{\mathrm{NR}}$ & 30 & 35 & 62 \\
\hline
\end{tabular}

n.d.: the $1 \mathrm{G}-$ model did not afford reliable $\mathrm{k}_{1}$ values.

a $\mathrm{G}_{01}$ : effective reactive pool; $\mathrm{k}_{1}$ : exponential decay rate constant of $\mathrm{G}_{01}\left(\mathrm{~d}^{-1}\right) ; \mathrm{G}_{\mathrm{NR}}$ : refractory pool. $\mathrm{G}_{01}$ and $\mathrm{G}_{\mathrm{NR}}$ are expressed in percentage of the initial amounts.

Table 2

Apparent first-order degradation constants $\left(k\right.$, day $\left.^{-1}\right)$, determination coefficients $\left(r^{2} ; n=15\right)$ and extent of degradation (E.D., \%) of the dominant extractable (free + esterified) individual fatty acids in sediment plugs incubated for 35 days under varying redox conditions

\begin{tabular}{lllll}
\hline Fatty Acid & \multicolumn{2}{c}{ Oxic } & Oscillating & Anoxic \\
\hline $\mathrm{C}_{16: 0} \mathrm{FA}$ & $k\left(r^{2}\right)$ & $0.030(0.89)$ & $0.018(0.77)$ & $0.011(0.87)$ \\
& $E . D$. & 70 & 58 & 44 \\
& & & & \\
$\mathrm{C}_{16: 1} \mathrm{FA}$ & $k\left(r^{2}\right)$ & $0.031(0.87)$ & $0.019(0.83)$ & $0.011(0.64)$ \\
& $E . D$. & 71 & 54 & 36 \\
$\mathrm{C}_{18: 1} \mathrm{FA}$ & $k\left(r^{2}\right)$ & $0.026(0.79)$ & $0.020(0.85)$ & $0.012(0.71)$ \\
& $E . D$. & 70 & 59 & 44 \\
\hline
\end{tabular}
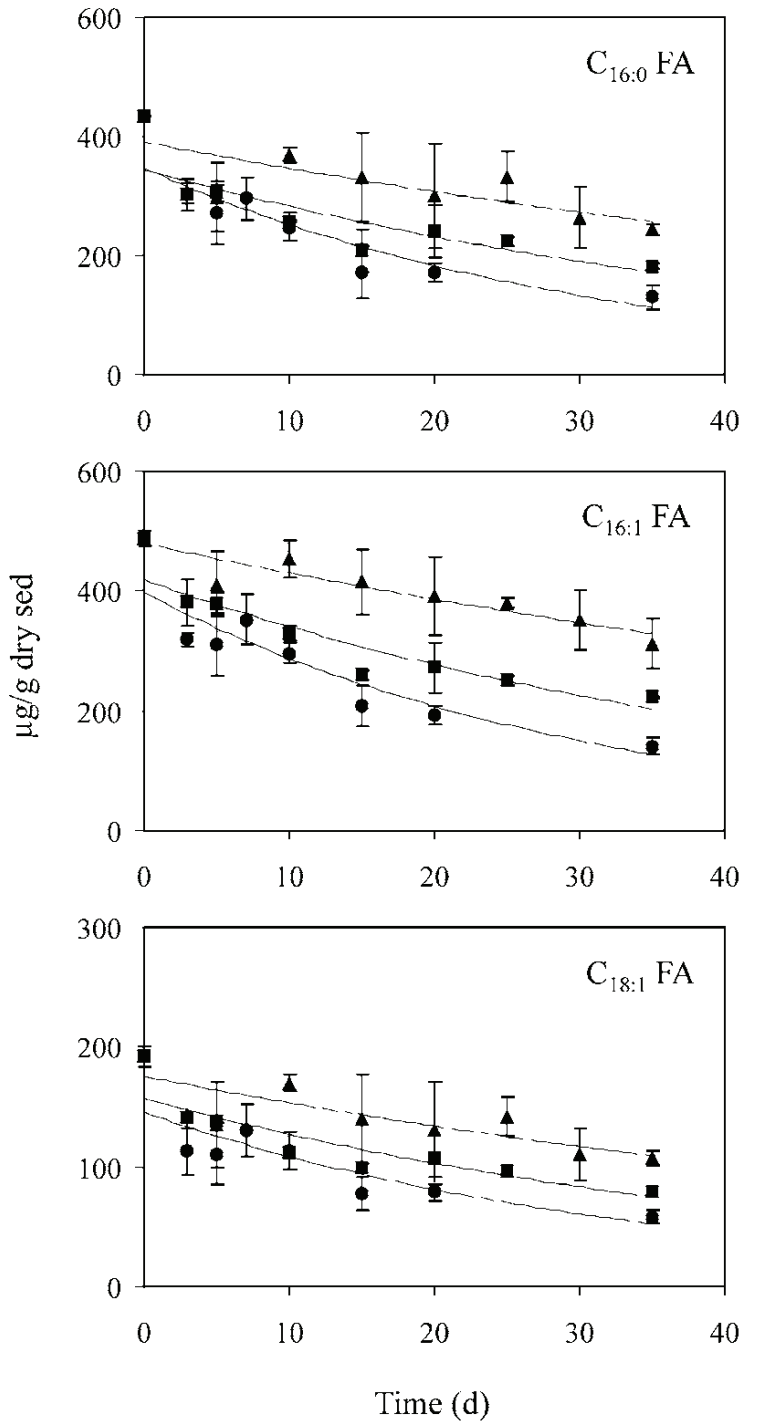

Fig. 4. Concentrations of individual "free + esterified" fatty acids during oxic $(\mathbf{O})$, oscillating $(\boldsymbol{\square})$ and anoxic $(\boldsymbol{\Delta})$ incubations of $N$. salina-enriched sediment plugs (each data point represents the average of duplicate samples \pm standard deviation). The solid lines are curves fitted to a first-order degradation model of the data (see Experimental). 
decrease in reactivity was observed from oxic $\left(0.029 \pm 0.003 \mathrm{~d}^{-1}\right)$ to oscillating conditions $(0.019 \pm$ $\left.0.001 \mathrm{~d}^{-1}\right)$ and then to anoxic conditions $(0.011 \pm 0.001$ $\mathrm{d}^{-1}$; Table 2).

\subsection{Formation of new compounds}

During the experiment, $\mathrm{C}_{15}$ and $\mathrm{C}_{17}$ branched chain bacterial acids were formed, but they never accounted for more than $2 \%$ of the total fatty acids present in the plugs, suggesting a relatively low bacterial contribution to the fatty acid pool. On the other hand, a production of saturated and monounsaturated $\mathrm{C}_{16}$ (and to a lesser extent $\mathrm{C}_{18}$ ) alkanols was observed in the plugs incubated under oscillating and anoxic redox conditions (Fig. 5). In both conditions of incubation, the concentration of these alcohols started to increase around day 5 and reached a maximum or plateau value around day 20 before dropping. The maximum concentrations of these newly produced alcohols varied in duration and magnitude depending on the redox conditions, the greatest accumulation being observed under anoxic conditions (Fig. 5).

\section{Discussion}

\subsection{Lipid composition of $\mathrm{N}$. salina}

The large amount of TG in the initial culture of $N$. salina is consistent with previous observations of high concentrations of these reserve lipids in Nannochloropsis cells. Volkman et al. (1993) and Schneider and Roessler (1994) observed that TG could represent $43-50 \%$ of the total lipids in Nannochloropsis species. Moreover, nitrogen deficient and light saturating conditions of growth of Nannochloropsis sp. resulted in very high proportions

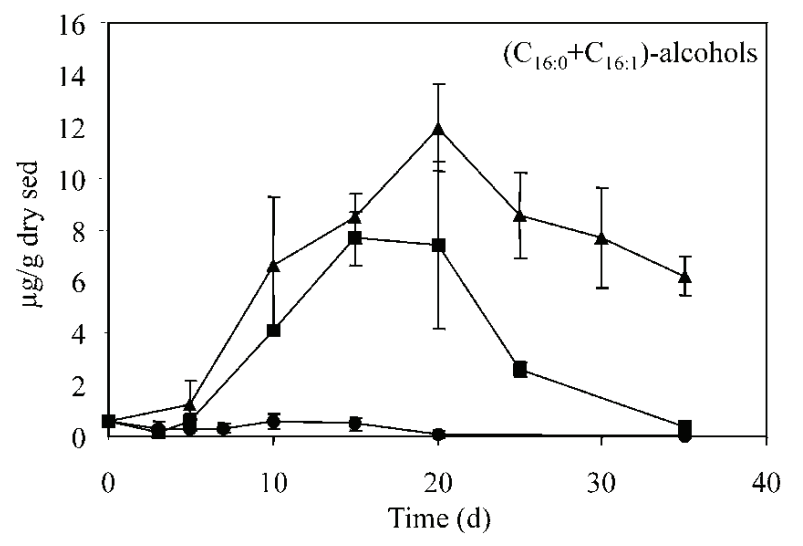

Fig. 5. Concentrations of $\left(\mathrm{C}_{16: 0}+\mathrm{C}_{16: 1}\right)$ alcohols during oxic $(\boldsymbol{O})$, oscillating $(\boldsymbol{\square})$ and anoxic $(\boldsymbol{\Delta})$ incubations of $N$. salinaenriched sediment plugs (each data point represents the average of duplicate samples \pm standard deviation).
(50-79\%) of TG in total lipids (Suen et al., 1987; Sukenik et al., 1989). As cells were harvested during the stationary phase, it is most likely that nutrient deficiency was responsible for the high $\mathrm{TG}$ content $(84 \%$ of total lipids) of $N$. salina cells used for the present study.

Also, $\mathrm{C}_{16: 0}, \mathrm{C}_{16: 1}$ and $\mathrm{C}_{18: 1}$ FA are classically reported as the major fatty acids of Nannochloropsis species, but they are generally accompanied by a large amount of eicosapentenoic acid $\mathrm{C}_{20: 5}$; (Volkman et al., 1993; Zhukova and Aizdaicher, 1995; Grossi et al., 2001). Schneider and Roessler (1994) did not detect this polyunsaturated fatty acid (PUFA) in the TG of a Nannochloropsis sp. culture, but found it in more polar lipid classes (monogalactosyl- and digalactosyl-diglycerides, phosphatidylglycerol). Sukenik et al. (1989) also showed that cells of Nannochloropsis sp. grown under saturating light exhibited high contents of $\mathrm{C}_{16: 0}$ and $\mathrm{C}_{16: 1} \mathrm{FA}$ and a low proportion of $\mathrm{C}_{20: 5} \mathrm{FA}$. In the present case, like the high proportion of $\mathrm{TG}$, the absence of $\mathrm{C}_{20: 5} \mathrm{FA}$ in $\mathrm{TG}$ as well as its very low concentration in the total lipids were likely due to nutrient limiting conditions at stationary phase and/or to saturating light exposure.

\subsection{Degradation of total lipids and TG vs. TOC in the sediment plugs}

In marine sediments, the relative proportions of labile and refractory components largely control the consumption rate of the OM pool and a wide range of decay rates have been reported for total pools and individual components (Westrich and Berner, 1984; Harvey and Macko, 1997; Sempéré et al., 2000; Hoefs et al., 2002; Panagiotopoulos et al., 2002). The different patterns of decay observed for TOC and $\mathrm{T}_{\text {Lip }}$ (Fig. 2a and b; Table 1) might be due to different proportions of labile organic matter within the two pools. Indeed, the addition of fresh microalgal cells to the sediment induced a significant input of labile molecules (i.e. sugars, proteins and lipids) which strongly contributed to the overall degradation pattern of TOC. On the other hand, this enrichment represented only a $54 \%$ increase in $\mathrm{T}_{\text {Lip }}$ due to the presence of (presumably refractory) lipids in the original sediment. Since $\mathrm{T}_{\text {Lip }}$ concentration rapidly reached a threshold value representing 44-59\% of the initial amount in the plugs (Table 1; Fig. 2b), it is likely that after the degradation of most reactive lipids, the original background lipids contributed significantly to the apparent non-degradable fraction $\left(\mathrm{G}_{\mathrm{NR}}\right)$.

The rapid decrease in TOC and $\mathrm{T}_{\mathrm{Lip}}$ concentrations is in good agreement with the trends observed during the experimental bacterial decomposition of natural phytoplanktonic communities (Westrich and Berner, 1984; Harvey et al., 1995; Teece et al., 1998). Calculated degradation rate constants for TOC $\left(\mathrm{k}_{1}=0.072-0.097\right.$ $\mathrm{d}^{-1}$; Table 1) were also in the same order of magnitude 
as those determined previously, using a $2 \mathrm{G}$-model, for the most reactive fraction of TOC in marine sediments (Westrich and Berner, 1984; Rabouille et al., 1998). Although initial TOC and TG decay rate constants appeared higher under anoxic conditions, the proportion of material that could be degraded throughout the $35 \mathrm{~d}$ period $\left(\mathrm{G}_{01}\right)$ was systematically higher under oxygenated conditions, suggesting a stronger capacity of aerobic processes to achieve low background concentrations of organic carbon in our experimental system.

\subsection{Influence of oxygen on TG hydrolysis and FA degradation}

The absence of MG and DG in the initial culture and their appearance together with FFA during oxic incubation (Fig. 3) demonstrated that hydrolysis of TG occurred (Goutx et al., 2003). The increase in the ratio (FFA $+\mathrm{MG}+1,2-\mathrm{DG}) / \mathrm{TG}$ observed during the oxic and the oscillating incubations showed that the presence of oxygen in sediments stimulates the hydrolysis of TG (Fig. 3). This might also be influenced by the oxygen exposure time (OET) as suggested by the time-lag between the peaks observed under oxic and oscillating conditions. In this multi-component system, hydrolysis products of TG (FFA, MG and DG) did not accumulate as shown by the fluctuating hydrolysis ratio (Fig. 3). Moreover, since FFA could be produced simultaneously from MG, DG and TG, a decrease in the above-defined ratio implied that the released FFA were further degraded, presumably at faster rates than the hydrolysis of acyl groups. This was supported by the steady decrease in concentration observed for individual (free + esterified) FA (Fig. 4). These observations are in good agreement with the results of Goutx et al. (2003) who observed the concomittant hydrolysis of tripalmitin and FFA production/degradation during aerobic TG decay in bacteria-inoculated seawater. Also, high rates of hydrolysis of FA-containing lipids have been reported during aerobic incubation conducted either with soils (Hita et al., 1996) or with archaeological ceramic potsherds (Dudd et al., 1998), and an accumulation of FFA was never observed. This reflects the capacity of aerobic bacterial communities from varied environments to easily hydrolyse FA-containing lipids and to subsequently mineralise the released FA. Conversely, the low values of the $(\mathrm{FFA}+\mathrm{MG}+1,2-\mathrm{DG}) / \mathrm{TG}$ ratio observed during the anoxic incubation (Fig. 3) suggested a low hydrolysis of TG to be likely due to a low efficiency of microorganisms to perform the hydrolysis of acyl groups in spite of their capacity to consume FFA. This agrees with the higher proportion of $\mathrm{TG}$ that remained in the plugs by the end of the anoxic incubation (ca. $62 \%$ of the initial amount), compared to oxic conditions (Table 1). The inefficiency of anaerobic bacteria to hydrolyse complex organic material has already been suggested (Kristensen et al., 1995; Hulthe et al., 1998; Kristensen and Holmer, 2001).

The degradation rate constants of individual (free + esterified) FA were consistent with those calculated for individual lipids in previous studies performed under either experimental (Grossi et al., 2003, and references therein) or natural (Canuel and Martens, 1996) conditions. They were, however, one to three orders of magnitude higher than those generally observed in strictly anoxic sediments (Sun and Wakeham, 1994; Grossi et al., 2001, 2003). Also, for the same FA under permanently oxic conditions Sun et al. (2002) observed higher (3-4 times) degradation rates compared to the present case. Differences in degradation rates from one study to the other may be due to varied bacterial communities/ metabolism (e.g. facultative vs strict anaerobes) and/or to different experimental systems involving distinct diffusion characteristics. It should also be emphasized that differences in incubation time can significantly influence the calculation of apparent degradation rate constants and that rate constants obtained using different kinetic models (e.g. taking into account a $\mathrm{G}_{\mathrm{NR}}$ fraction or not, see Experimental) cannot be compared.

The extent and rates of degradation of individual (free + esterified) FA under oscillating conditions were within the interval of values calculated for oxic and anoxic incubations (Table 2). This is consistent with previous trends obtained either with similar open incubation systems (Sun et al., 1993, 2002) or with bioturbated sediment cores (Grossi et al., 2003). Obviously, redox oscillation corresponds to an intermediate OET in comparison with oxic and anoxic exposure, likely resulting in an intermediate state of organic matter decomposition. Previous studies have shown, however, that redox oscillation can lead to a more complete decomposition of organic matter compared to oxic or anoxic conditions alone (Hulthe et al., 1998) or result in diagenetic properties more characteristic of completely oxidized conditions (Aller, 1994; Grossi et al., 2003). In the present study, this latter feature was essentially verified for TG (and to a lesser extent for TOC and $\mathrm{T}_{\mathrm{Lip}}$ ) which showed a reactive fraction $\left(\mathrm{G}_{01}\right)$ under oscillating conditions much closer to the one observed for oxic incubations, independently of their apparent degradation rates (Table 1). The intermediate degradation observed for individual FA might be due to the the fact that their concentrations were still decreasing after 35 days of incubation (Fig. 4). Using different oscillation frequencies, Sun et al. (2002) demonstrated that individual planktonic lipids degrade faster when the oscillation was more frequent and exposure time to oxygen was longer in duration. These observations together with our results for TG degradation support the theory, at the level of specific (class of) organic molecules, that organic carbon degradation/preservation in continental 
margin sediments is largely controlled by OET (Hartnett et al., 1998; Hedges et al., 1999).

\subsection{Possible degradation pathways}

During the incubation of a ${ }^{13} \mathrm{C}$-labelled green alga (Chlorella) under varying conditions of oxygenation, Sun et al. (2002) observed the production of uniformlylabelled hexadecanol under anoxic and oscillating redox conditions. The authors suggested that it could be derived from reduction of labelled $\mathrm{C}_{16: 0}$ fatty acid, which was the most abundant lipid component in the ${ }^{13} \mathrm{C}$-labelled alga. The noticeable production of saturated and monounsaturated $\mathrm{C}_{16}$ and $\mathrm{C}_{18}$ fatty alcohols during our oscillating and anoxic incubations (see Fig. 5 for $\mathrm{C}_{16}$ ) might also be explained by the reduction of a proportion of the corresponding fatty acids under anoxic conditions, following the hydrolysis of acylglycerols (TG, DG and MG). The production of fatty alcohols coincided with a high level of TG hydrolysis (Figs. 2 and 5), which supports a precursor-product relationship between FA esterified to TG and the alcohols detected. The greater accumulation of $\mathrm{C}_{16}$ alcohols observed under anoxic conditions (Fig. 5) might reflect a lower efficiency of anaerobic bacteria for mineralising these compounds. For the oscillating conditions, it is possible that alcohols were produced under anoxia and consumed during oxic periods. This suggests that aerobic and anaerobic bacteria in the plugs used different assimilation pathways.

\section{Conclusions}

Incubation of microalgal cells in an experimental sedimentary system demonstrated that changes in redox condition can significantly affect the fate of fatty acid-containing macromolecular lipids such as TG. The presence of oxygen, either continuous or periodic, stimulates TG hydrolysis and the subsequent degradation of released metabolites (e.g. FFA), and leads to lower residual concentrations of such lipids than under anoxic conditions. This further emphasizes the importance of oscillating redox conditions induced by benthic macro- and meio-fauna in bioturbated sediments in regulating the degradation of oxygen-sensitive components.

The varying patterns of degradation observed under controlled conditions for both bulk parameters (TOC, $\mathrm{T}_{\text {Lip }}$ ) and specific lipids (TG, individual FA) reinforces the idea that bulk parameters used to approximate the degradation of major biochemicals may be misleading as they integrate varying rates for individual compounds. On the other hand, this further highlights the necessity of using appropriate kinetic models in order to calculate reliable diagenetic parameters.

\section{Acknowledgements}

This work was funded by the program ATI 1998 (CNRS- INSU; grants to V.G. and F.G.). We thank Ms D. Raphel for help with microalgal culture, Dr. F. Van Wambeke for help in the calculation of $1 \mathrm{G}$-model parameters and Ms C. Griffin for careful English reading. We are grateful to Dr. Mark Teece, Dr. J.K. Volkman and two anonymous reviewers for constructive suggestions about an earlier version of the paper. This is Nereis Park contribution number 004.

\section{Associate Editor - J.K. Volkman}

\section{References}

Aller, R.C., 1994. Bioturbation and remineralization of sedimentary organic matter: effects of redox oscillation. Chemical Geology 114, 331-345.

Aller, R.C., Aller, J.Y., Kemp, P.F., 2001. Effects of particle and solute transport on rates and extent of remineralization in bioturbated sediments. In: Aller J.Y., Woodin S.A., Aller R.C. (Eds.), Organism-Sediment Interactions. University of South Carolina Press, pp. 315-333.

Aller, R.C., Mackin, J.E., 1989. Open-incubation, diffusion methods for measuring solute reaction rates in sediments. Journal of Marine Research 47, 411-440.

Bianchi, T.S., Johansson, B., Elmgren, R., 2000. Breakdown of phytoplankton pigments in Baltic sediments: effects of anoxia and loss of deposit-feeding macrofauna. Journal of Experimental Marine Biology and Ecology 251, 161-183.

Canuel, E.A., Martens, C.S., 1996. Reactivity of recently deposited organic matter: degradation of lipid compounds near the sediment-water interface. Geochimica et Cosmochimica Acta 60, 1793-1806.

Dudd, S.N., Regert, M., Evershed, R.P., 1998. Assessing microbial lipid contributions during laboratory degradations of fats and oils and pure triacylglycerols absorbed in ceramic potsherds. Organic Geochemistry 29, 1345-1354.

Forster, S., Graf, G., 1992. Continuously measured changes in redox potential influenced by oxygen penetrating from burrows of Callianassa subterranea. Hydrobiologia 235/236, 527-532.

Gilbert, F., Aller, R.C., Hulth, S., 2003. The influence of macrofaunal burrow spacing and diffusive scaling on sedimentary nitrification and denitrification: an experimental simulation and model approach. Journal of Marine Research 61, 101-125.

Gilbert, F., Rivet, L., Bertrand, J.-C., 1994. The in vitro influence of the burrowing polychaete Nereis diversicolor on the fate of petroleum hydrocarbon in marine sediments. Chemosphere 29, 1-12.

Gilbert, F., Stora, G., Bertrand, J.-C., 1996. In situ bioturbation and hydrocarbon fate in an experimental contaminated Mediterranean coastal ecosystem. Chemosphere 33, 14491458.

Goutx, M., Guigue, C., Striby, L., 2003. Triacylglycerol biodegradation experiment in marine environmental conditions: definition of a new lipolysis index. Organic Geochemistry 34, 1465-1473. 
Grossi, V., Blokker, P., Sinninghe Damsté, J.S., 2001. Anaerobic biodegradation of lipids of the marine microalga Nannochloropsis salina. Organic Geochemistry 32, 795-808.

Grossi, V., Caradec, S., Gilbert, F., 2003. Burial and reactivity of sedimentary microalgal lipids in bioturbated Mediterranean coastal sediments. Marine Chemistry 81, 57-69.

Grossi, V., Massias, D., Stora, G., Bertrand, J.-C., 2002. Burial, exportation and degradation of acyclic petroleum hydrocarbons following a simulated oil spill in bioturbated Mediterranean coastal sediments. Chemosphere 48, 947-954.

Hartnett, H.E., Keil, R.G., Hedges, J.I., Devol, A.H., 1998. Influence of oxygen exposure time on organic carbon preservation in continental margin sediments. Nature 391, 572 574.

Harvey, H.R., Macko, S.A., 1997. Kinetics of phytoplankton decay during simulated sedimentation: changes in lipids under oxic and anoxic conditions. Organic Geochemistry 27, $129-140$.

Harvey, H.R., Tuttle, J.H., Macko, S.A., 1995. Kinetics of phytoplankton decay during simulated sedimentation: changes in biochemical composition and microbial activity under oxic and anoxic conditions. Geochimica et Cosmochimica Acta 59, 3367-3377.

Hedges, J.I., Hu, F.S., Devol, A.H., Hartnett, H.E., Tsamakis, E., Keil, R.G., 1999. Sedimentary organic matter preservation: a test for selective degradation under oxic conditions. American Journal of Sciences 299, 529-555.

Hedges, J.I., Prahl, F.G., 1993. Early diagenesis consequences for applications of molecular biomarkers. In: Engel, M.H., Macko, S.A. (Eds.), Organic Geochemistry. Plenum Press, New York, pp. 237-253.

Hita, C., Parlanti, E., Jambu, P., Joffre, J., Amblès, A., 1996. Triglyceride degradation in soil. Organic Geochemistry 25, 19-28.

Hoefs, M.J.L., Rijpstra, W.I.C., Sinninghe Damsté, J.S., 2002. The influence of oxic degradation on the sedimentary biomarker record I: evidence from Madeira Abyssal Plain turbidites. Geochimica et Cosmochimica Acta 66, 2719-2735.

Hulthe, G., Hulth, S., Hall, P.O.J., 1998. Effect of oxygen on degradation rate of refractory and labile organic matter in continental margin sediments. Geochimica et Cosmochimica Acta 62, 1319-1328

Ingalls, A.E., Aller, R.C., Lee, C., Sun, M.-Y., 2000. The influence of deposit-feeding on chlorophyll- $a$ degradation in coastal marine sediments. Journal of Marine Research 58, 631-651.

Kristensen, E., Ahmed, S.I., Devol, A.H., 1995. Aerobic and anaerobic decomposition of organic matter in marine sediment: which is fastest? Limnology and Oceanography 40, 1430-1437.

Kristensen, E., Blackburn, T.H., 1987. The fate of organic carbon and nitrogen in experimental marine sediment systems: influence of bioturbation and anoxia. Journal of Marine Research 45, 231-257.

Kristensen, E., Holmer, M., 2001. Decomposition of plant materials in marine sediment exposed to different electron acceptors $\left(\mathrm{O}_{2}, \mathrm{NO}_{3}\right.$ and $\left.\mathrm{SO}_{4}^{2-}\right)$, with emphasis on substrate origin, degradation kinetics, and the role of bioturbation. Geochimica et Cosmochimica Acta 65, 419-433.

Lee, C., 1992. Controls on organic preservation: the use of stratified water bodies to compare intrinsic rates of decom- position in oxic and anoxic systems. Geochimica et Cosmochimica Acta 56, 3323-3335.

Panagiotopoulos, C., Sempéré, R., Obernosterer, I., Striby, L., Goutx, M., Wambeke, F.V., Gautier, S., Lafont, R., 2002. Bacterial degradation of large particles in the southern Indian Ocean using in vitro incubation experiments. Organic Geochemistry 33, 985-1000.

Parrish, C.C., 1988. Dissolved and particulate marine lipid classes: a review. Marine Chemistry 23, 17-40.

Rabouille, C., Gaillard, J.F., Relexans, J.C., Treguer, P., Vincendeau, M.A., 1998. Recycling of organic matter in Antarctic sediments: a transect through the polar front in the southrn Ocean (Indian Sector). Limnology and Oceanography 43, 420-432.

Schaaff, E., Grenz, C., Pinazo, C., 2002. Erosion of particulate inorganic and organic matter in the Gulf of Lion. Comptes Rendus de l'Académie des Sciences, Géosciences 334, 10711077.

Schneider, J.C., Roessler, P., 1994. Radiolabeling studies of lipids and fatty acids in Nannochloropsis (Eustigmatophyceae), an oleaginous marine alga. Journal of Phycology 30, 594-598.

Sempéré, R., Yoro, S.C., Van Wambeke, F., Charrière, B., 2000. Microbial decomposition of large organic particles in the Northwestern Mediterranean Sea: an experimental approach. Marine Ecology Progress Series 198, 61-72.

Sinninghe Damsté, J.S., Rijpstra, W.I., Reichart, G.-J., 2002. The influence of oxic degradation on the sedimentary biomarker record II. Evidence from Arabian Sea sediments. Geochimica et Cosmochimica Acta 66, 2737-2754.

Striby, L., Lafont, R., Goutx, M., 1999. Improvement in the Iatroscan thin-layer chromatographic-flame ionisation detection analysis of marine lipids. Separation and quantitation of monoacylglycerols and diacylglycerols in standards and natural samples. Journal of Chromatography A 849, 371-380.

Suen, Y., Hubbard, J.S., Holzer, G., Tornabene, T.G., 1987. Total lipid production of the green alga Nannochloropsis sp. QII under different nitrogen regimes. Journal of Phycology 23, 289-296.

Sukenik, A., Carmeli, Y., Berner, T., 1989. Regulation of fatty acid composition by irradiance level in the Eustigmatophyte Nannochloropsis sp.. Journal of Phycology 25, 686-692.

Sun, M.-Y., Aller, R.C., Lee, C., Wakeham, S.G., 1999. Enhanced degradation of algal lipids by benthic macrofaunal activity: effect of Yoldia limatula. Journal of Marine Research 57, 775-804.

Sun, M.-Y., Aller, R.C., Lee, C., Wakeham, S.G., 2002. Effects of oxygen and redox oscillation on degradation of cell-associated lipids in surficial marine sediments. Geochimica et Cosmochimica Acta 66, 2003-2012.

Sun, M.-Y., Lee, C., Aller, R.C., 1993. Laboratory studies of oxic and anoxic degradation of chlorophyll- $a$ in Long Island Sound sediments. Geochimica et Cosmochimica Acta 57, 147-157.

Sun, M.-Y., Wakeham, S.G., 1994. Molecular evidence for degradation and preservation of organic matter in the anoxic Black Sea Basin. Geochimica et Cosmochimica Acta 58, 3395-3406.

Sun, M.-Y., Wakeham, S.G., Lee, C., 1997. Rates and mechanisms of fatty acids degradation in oxic and anoxic 
coastal marine sediments of Long Island Sound, New York, USA. Geochimica et Cosmochimica Acta 61, 341-355.

Teece, M.A., Getliff, J.M., Leftley, J.W., Parkes, R.J., Maxwell, J.R., 1998. Microbial degradation of the marine prymnesiophyte Emiliania huxleyi under oxic and anoxic conditions as a model for early diagenesis: long chain alkadienes, alkenones and alkyl alkenoates. Organic Geochemistry 29, 863-880.

Volkman, J.K., Brown, M.R., Dunstan, G.A., Jeffrey, S.W.,
1993. The biochemical composition of marine microalgae from the class Eustigmatophyceae. Journal of Phycology 29, 69-78.

Westrich, J.T., Berner, R.A., 1984. The role of sedimentary organic matter in bacterial sulfate reduction: the $G$ model tested. Limnology and Oceanography 29, 236-249.

Zhukova, N.V., Aizdaicher, N.A., 1995. Fatty acid composition of 15 species of marine microalgae. Phytochemistry 39, $351-356$. 